\title{
A Takeover Strategy Based on the Business Analysis of Transportation and Real Estate Industry
}

\author{
Zhe $\mathrm{Wu}$ \\ Finance Department, Monash University, Melbourne, Australia
}

\begin{abstract}
This paper aims to find out two proper target firms and make a proper advice for M\&A, thus providing a method of how to assess the possible merger and acquisition. This paper will make suggestions for Jaffa Ltd, since it is an influential Australian based commodities trading company which encounter a dilemma of decreasing growth. Since the whole industry has the same problem, acquiring other newly developing companies from different industries will be a good strategy for this kind of companies that own a large amount of cash yet has difficulty in developing in its own field. With the business analysis, Jaffa Ltd is supposed to take over GMG and AZJ.
\end{abstract}

\section{INTRODUCTION}

To find the proper firms, this paper focuses on economic outlook and ratio analysis to narrow the industries scope and filter the most suitable two firms from the 61 firms, shown in Table 1(Only part of them are exhibited). These 61 firms are the leading enterprises in each industry. The capital structure of two firms will be a major concern, which affects the valuations of them. Furthermore, in order to further analyze the value of these two firms, the WACC(Weighted Average Cost of Capital) and sustainable growth rate are also be used. Different valuation methods have different assumptions. For example, when using FCFF method, this paper assumes the future growth of company's sales and costs. Normally, for a fast-developing company, Two-stages approach is used to evaluate the future cash flow. In early stage, the author assumes that the company will go through a quick developing period and then return to a normal development period.

\section{SELECTION OF TARGET FIRMS}

The target firms selected are Aurizon Holdings Limited (AZJ) and Goodman Group (GMG). Aurizon Holdings Limited is a rail freight operator, it builds the network of rail for the transportation of coal and iron ore, and also to update other existing rail line for the coal and iron ore Furthermore, it transports coals and iron ores to the ports for the export market, and transports mineral commodities and agricultural products throughout Australia. Another target firm is Goodman Group. Goodman Group provides property investment and management of business property services such as office building, business parking lots. Its property investment portfolio is composed of 411 industrial businesses and properties in 16 countries and it manages more than 70 projects of property development in 11 countries (Morningstar's Data Analysis Premium, 2016).

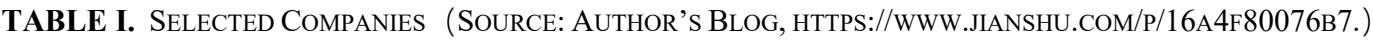

\begin{tabular}{|c|c|c|}
\hline Ticker & Name & Industry \\
\hline $1 \mathrm{ABC}$ & ADELAIDE BRIGHTON & Building Mat Fix \\
\hline $2 \mathrm{AlO}$ & ASCIANO & Railroads \\
\hline $3 \mathrm{ALQ}$ & ALS & NondurHousehold Prod \\
\hline $4 \mathrm{AMC}$ & AMCOR & Containers Package \\
\hline 5 AMP & AMP & Life Insurance \\
\hline 6 ANZ & AUS.AND NZ.BANKING GP. & Banks \\
\hline 7 APA & APA GROUP & Pipelines \\
\hline 8 ASX & ASX & Investment Services \\
\hline 9 AWE & AWE & Exploration Prod \\
\hline
\end{tabular}

The first step is to analyze 61 firms based on their industries from the Macroeconomic environment. The analysis for the Macroeconomic condition is divided into two parts, international and domestic economic conditions. In terms of the international outlook, based on the data on the OECD (2015), the export value accounts for the GDP of Australia is around 19\%, this number is even higher than the U.S. and Japan. As figure 1 shows, the mining accounts for the GDP of Australia about $24.54 \%$. 


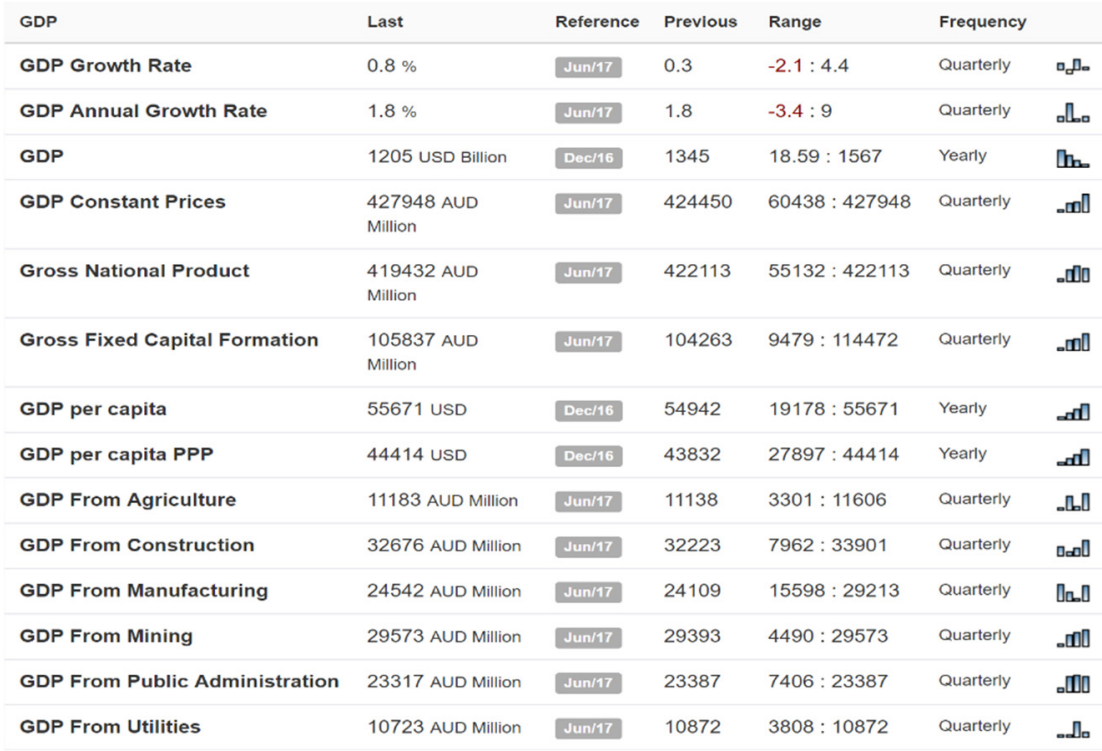

Figure I. GDP of Australia (SOURCE: Australia | EConOmic Indicators)

Furthermore, the export of mining is the largest part of total exportation (Composition of trade Australia ,2016). Meanwhile, China accounts for the biggest part for the exported goods and services, and the major goods exported to China are Iron ore and concentrates(Australia's export performance, 2016). However, that demand is decreasing. Hence, this paper should avoid the company only operate businesses are only relating to the mining when this paper consider the proper industries. Hence, some supplier chain for this kind of industries would be considered, such as transportation. In terms of the domestic data, the population and car numbers of the Australia is increasing stably every year(Trading Economics, 2017), which implies that the
Australia market is expanding, in other words, more and more firms would build more shopping centers, or office buildings to exploit Australia potential market, therefore, this paper considers some companies that are related to the real estate. Therefore, based on these analysis, this paper selects the industries relating to transportation and real estate.

\section{CAPITAL STRUCTURE OF TARGET FIRMS}

\subsection{Analysis of Capital Structure}

TABLE II. DebT AND Share of ThreE COMPANIES

\begin{tabular}{|c|c|c|c|c|c|c|}
\hline & AZ] & & GMG & & \multicolumn{2}{|l|}{ Jaffa } \\
\hline Cost of debt & & 0.0423 & & 0.0423 & & 0.07 \\
\hline Stock price on 30/06/2015 & $\$$ & 5.13 & $\$$ & 6.27 & $\$$ & 27.20 \\
\hline Share outstanding & $\$$ & $2,122,010,000.00$ & $\$$ & $1,753,035,922.00$ & $\$$ & $1,000,000,000.00$ \\
\hline Spread & & $1.60 \%$ & & $1.60 \%$ & N.A & \\
\hline RF & $\$$ & 0.03 & $\$$ & 0.03 & & 0.0263 \\
\hline interest expense & $\$$ & $144,000,000.00$ & $\$$ & $15,000,000.00$ & & 19040000000 \\
\hline Average maturity & & $430.00 \%$ & & $470.00 \%$ & N.A & \\
\hline Market value of equity & & $1088591130000.00 \%$ & & $1099153523094.00 \%$ & $\$$ & $272,000,000,000.00$ \\
\hline
\end{tabular}

- All data period in this section used is on $30 / 6 / 2015$.

- Jaffa: because the information about the Jaffa given is limited, this paper assumes that its market value and book value are the same.

- The market value of equity: is calculated by using share price on the 30th of June 2015 to multiply their share outstanding. The share price of these two companies are quoted from Yahoo finance (2017), and their share outstanding are quoted from their annual report in 2015.

- The market value of debt: is calculated by using the formula 1 , and the cost of debt is $4.23 \%$, it is calculated by using the spread to plus the risk-free rate. The rating of $\mathrm{AZJ}$ is $\mathrm{BBB}+\mathrm{Baal}$ (Aurizon Holding Limited, 2015). The rating of GMG is BBB. Based on the Table 2, both the spread of these two companies are $1.6 \%$. The debt maturity of GMG and AZJ is quoted from their annual report.

- Risk-free rate: this paper used is the Australia 10-year Treasury bond rate. From the market premia (2017), in 1st of January 2016, the rate is $2.63 \%$.

- The market value of short-term debt and long-term debt: are simply used the same percentage accounts for the total debt with the book value. 


$$
\text { Market valud of Debt }=\text { interest expense } *\left(\frac{\frac{1}{(1+\cos t \text { of debt })^{t}}}{\operatorname{cost~of~debt~}}\right)+\left(\text { FVof Debt } /(1+\operatorname{cost} \text { of debt })^{t}\right.
$$

For large non-financial service companies with market cap $>\$ 5$ billion

\begin{tabular}{|c|c|c|c|}
\hline If interest coverage ratio is & Column1 & Column2 & Column3 \\
\hline$>$ & $\leq$ to & Rating is & Spread is \\
\hline 8.50 & 100000 & Aaa/AAA & $0.60 \%$ \\
\hline 6.5 & 8.499999 & Aa2/AA & $0.80 \%$ \\
\hline 5.5 & 6.499999 & $\mathrm{~A} 1 / \mathrm{A}+$ & $1.00 \%$ \\
\hline 4.25 & 5.499999 & $\mathrm{~A} 2 / \mathrm{A}$ & $1.10 \%$ \\
\hline 3 & 4.249999 & $\mathrm{~A} 3 / \mathrm{A}-$ & $1.25 \%$ \\
\hline 2.5 & 2.999999 & $\mathrm{Baa} 2 / \mathrm{BBB}$ & $1.60 \%$ \\
\hline 2.25 & 2.49999 & $\mathrm{Ba} 1 / \mathrm{BB}+$ & $2.50 \%$ \\
\hline 2 & 2.2499999 & $\mathrm{Ba} 2 / \mathrm{BB}$ & $3.00 \%$ \\
\hline 1.75 & 1.999999 & $\mathrm{~B} 1 / \mathrm{B}+$ & $3.75 \%$ \\
\hline 1.5 & 1.749999 & $\mathrm{~B} 2 / \mathrm{B}$ & $4.50 \%$ \\
\hline 1.25 & 1.499999 & $\mathrm{~B} 3 / \mathrm{B}-$ & $5.50 \%$ \\
\hline 0.8 & 1.249999 & $\mathrm{Caa} / \mathrm{CCC}$ & $6.50 \%$ \\
\hline 0.65 & 0.799999 & $\mathrm{Ca} 2 / \mathrm{CC}$ & $8.00 \%$ \\
\hline 0.2 & 0.649999 & $\mathrm{C} 2 / \mathrm{C}$ & $10.50 \%$ \\
\hline-100000 & 0.199999 & $\mathrm{D} 2 / \mathrm{D}$ & $14.00 \%$ \\
\hline
\end{tabular}

Figure II. Ratings (Source: Ratings, Interest Coverage Ratios and Default Spread)

\subsection{Capital structure}

This part depicts the capital structure of AZJ and GMG from two sides, book value and market value. In terms of the book value, as the table 3 shows, the AZJ 's book value of equity and debt are $\$ 6506$ million and $\$ 2983$ million, respectively. Its D/E ratio is $45.85 \%$. The GMG's equity and debt value are $\$ 7376.1$ million and $\$ 2707.9$ million and its $\mathrm{D} / \mathrm{E}$ ratio is less than $\mathrm{AZJ}, 36.71 \%$. The reason for this difference is that the liquidity of REITs would be weak. In other words, they should carefully control their debt, then they would have more flexibility. Therefore, The capital management strategy is aiming to minimize its financial leverage to further offset risk. In terms of the market value, both their $\mathrm{D} / \mathrm{E}$ ratios are less than their book value D/E ratio, GMG 21.14\%, and D/E ratio of $\mathrm{AZJ}$ is $28.03 \%$. This is due to their market value of equity, which is significantly increased. The market equity value of AZJ increases by $\$ 4379.9$ million and GMG increases by $\$ 3615.4$ million. Moreover, as the table 3 shows, AZJ has more debt than the GMG no matter short-term or long-term debt. In terms of the stocks, both companies don not have preferred stock on their balance sheet, while the value of common stock of AZJ is more than that of GMG.

The debt of GMG is composed of bank loans, foreign private placement, U.S. and Euro senior notes. As the Figure 8 shows, the U.S bond accounts for the largest part of its debt, $\$ 1719$ million. For the debt construction of AZJ, based on the figure 4 , it is formed by various facilities and medium-term notes, it is different with the composition of GMG, its major part of its debt is bank facilities rather than the bonds, $\$ 1690$ million.

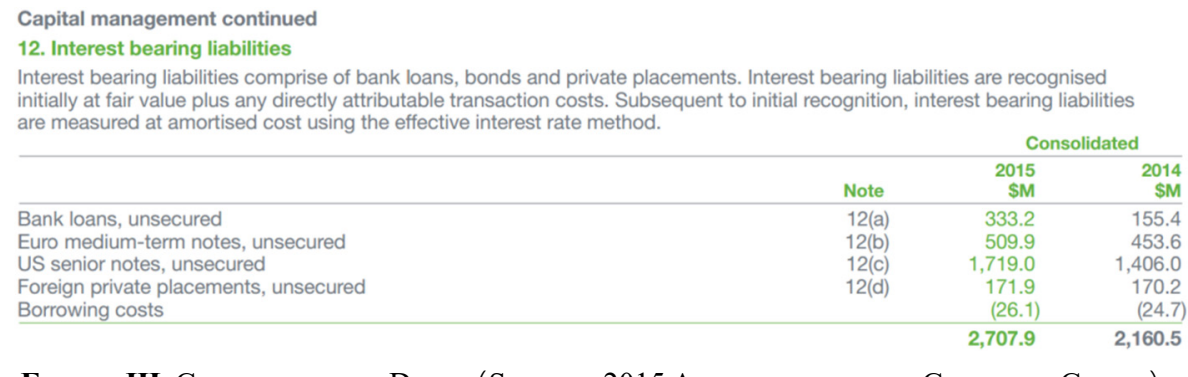

Figure III. Composition of Debt （Source: 2015 AnNuAl Report of Goodman Group） 


\section{Borrowings}

\begin{tabular}{|c|c|c|}
\hline \multicolumn{3}{|c|}{$\begin{array}{l}\text { KEEPING IT SIMPLE } \\
\text { The Group borrows money through bank debt facilities and } \\
\text { through the issuance of debt securities in capital markets. }\end{array}$} \\
\hline & $\begin{array}{r}2015 \\
\$ \mathrm{~m}\end{array}$ & $\begin{array}{r}2014 \\
\$ \mathrm{~m}\end{array}$ \\
\hline \multicolumn{3}{|l|}{ Current - Unsecured } \\
\hline \multirow[t]{2}{*}{ Working capital facility } & 59 & 42 \\
\hline & 59 & 42 \\
\hline \multicolumn{3}{|l|}{ Non-current - Unsecured } \\
\hline Medium-term notes & 1,250 & 518 \\
\hline Bank facilities & 1,690 & 2,310 \\
\hline Capitalised borrowing costs & (16) & (29) \\
\hline
\end{tabular}

Figure IV. BorrowingS （SOURCE: 2015 ANnuAl Report of Aurizon Holding Limited）

TABLE III. Book VALUe AND MARKet VALU

\begin{tabular}{|c|c|c|c|c|c|c|}
\hline \multicolumn{7}{|c|}{ Book value } \\
\hline \multirow[b]{2}{*}{ Book value of debt } & \multicolumn{2}{|c|}{$\triangle 21$} & \multicolumn{2}{|c|}{ GMG } & \multicolumn{2}{|c|}{ Jafffa } \\
\hline & $\$$ & $2,063,000,00000$ & $\$$ & $2,70 \pi, 000,00000$ & $\$$ & $80,000,000,00000$ \\
\hline Book value of equity & $\$$ & $6,506,000,00000$ & $\$$ & $8,376,100,00000$ & $\$$ & $272,000,000,00000$ \\
\hline D/E & & $4585 \pi$ & & $36 \pi 14$ & & $2206 \mathrm{~m}$ \\
\hline Short-term debt & $\$$ & $59,000,00000$ & $\$$ & - & NA & \\
\hline Long-term debt & $\$$ & $2,924,000,00000$ & $\$$ & $2,70 \pi, 000,0000$ & NA & \\
\hline ST debt/total debt & & 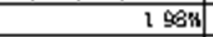 & & $000 \%$ & $N A$ & \\
\hline LT debt/total debt & & $9602 \pi$ & & 100000 & NA & \\
\hline Common stock & & $4,97,000,00000$ & & $7,936,000,00000$ & $N A$ & \\
\hline Ordinary shares & & $2,122,010,00000$ & & $1,753,025,92200$ & & $1,000,000,00000$ \\
\hline Preferred stock & & 000 & & 000 & NA & \\
\hline Treasury stock & & - $10,000,00000$ & & $-132,000,00000$ & $N A$ & \\
\hline \multicolumn{7}{|c|}{ Market value } \\
\hline & $\sqrt{A 2 D}$ & & $\overline{\text { GMG }}$ & & Daffa & \\
\hline Market value of debt & $\$$ & $3,051,741,11156$ & $\$$ & $2,323,856,39130$ & $\$$ & $80,000,000,00000$ \\
\hline Market value of equity & $\$$ & $10,835,911,30000$ & $\$$ & $10,991,535,230 \mathrm{Q4}$ & $\$$ & $272,000,000,00000$ \\
\hline$D / E$ & & $2803 \pi$ & & 21144 & & $2206 \mathrm{~m}$ \\
\hline Short-tem debt & $\$$ & 80359.61300 & $\$$ & - & NA & \\
\hline Long-term debt & $\$$ & $2,991,891,49856$ & $\$$ & $2,323,856,39130$ & NA & \\
\hline ST debt/total debt & & $1 \leq 6$ & & $000 \mathrm{~m}$ & NR & \\
\hline LT debt/total debt & & $9602 \pi$ & & $10000 \%$ & NA & \\
\hline
\end{tabular}

Table IV. Key Elements for Calculating Beta

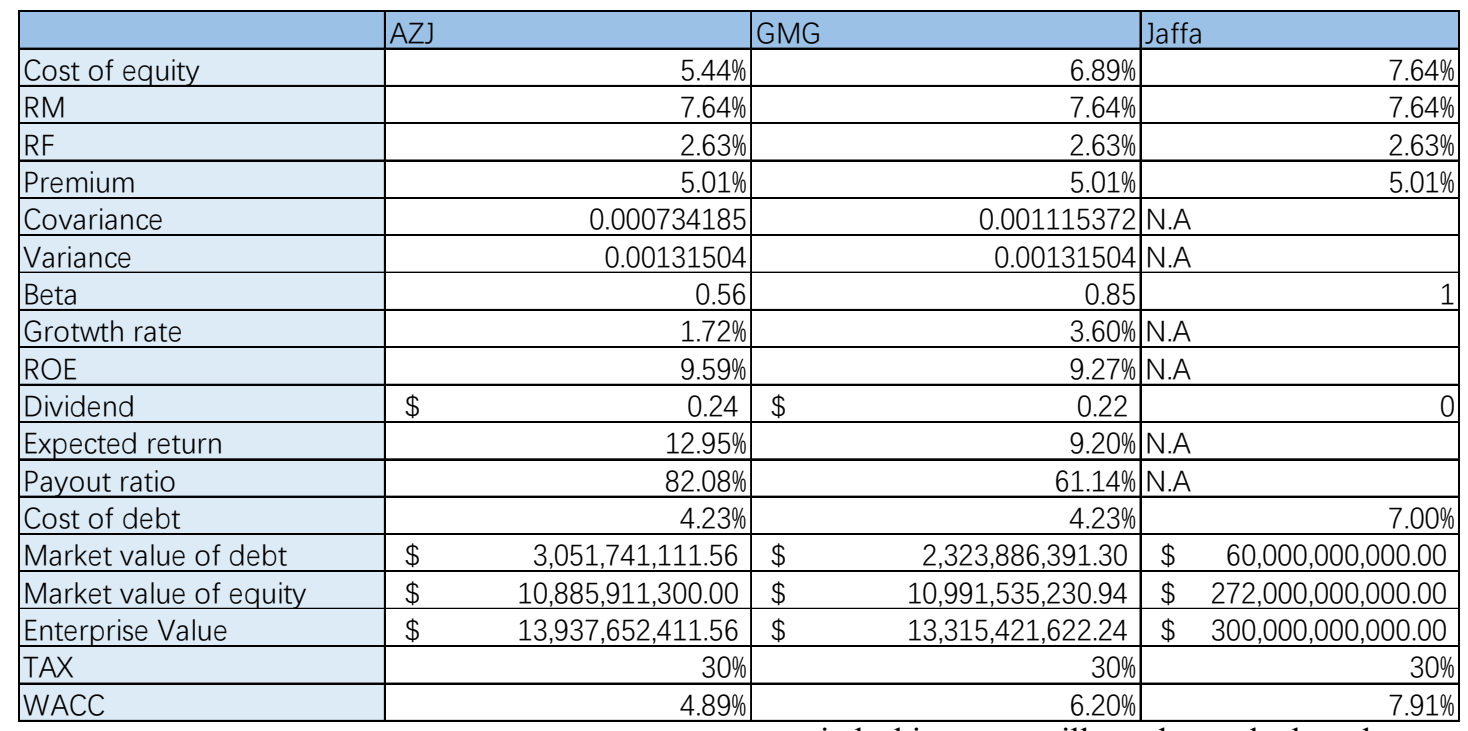

capital, this paper will need to calculate the cost of debt

\section{COST OF CAPITAL AND SUSTAINABLE GROWTH RATE}

The cost of capital of AZJ and GMG is $4.89 \%$ and $6.20 \%$, while that of Jaffa is $7.91 \%$. To calculate the cost of and equity as well as market value of debt and equity. All these inputs are derived from the section two except for the cost of equity. The cost equity is calculated by the CAPM formula:

cost of equity $=$ risk-free rate + beta*(expected market return-risk-free rate). 
The period of risk-free rate, expected market return this paper used is in January of 2016, and they are 2.63\% and 7.64\%, respectively (Market-Risk-Premia, 2017).

For the Jaffa's beta, this paper decide to use the raw data beta one as its beta, the reason is that the beta should be calculated based on the company's historical data, but the information only shows some basic information, hence, this paper decided to use the raw beta. For target firms' beta, it is calculated by the.

$$
\beta_{p}=\frac{\operatorname{Cov}\left(r_{p}, r_{b}\right)}{\operatorname{Var}\left(r_{b}\right)}
$$

The data that this paper used to calculate the beta are from ASX200, all of the time period is from January of 2011 to January of 2016. As the table 4 shown, the cost of equity of AZJ and GMG is $5.44 \%$ and $6.89 \%$, respectively. Then, using WACC formula: WACC= $\mathrm{rD}^{*}(1-\mathrm{Tc})^{*}(\mathrm{D} / \mathrm{V})+\mathrm{rE}^{*}(\mathrm{E} / \mathrm{V})$. Thus, these two target companies' WACC are $4.89 \%$ and $6.20 \%$, and the Jaffa is $7.09 \%$.

According to table 4, the sustainable growth rate of AZJ and GMG is $1.72 \%$, and $3.60 \%$ respectively. To calculate the sustainable growth rate, the formula this paper used is:

Growth rate $=(1$-Payout ratio $) *$ ROE. The payout ratio and $\mathrm{ROE}$ are from this two companies' annual report (2015).

The expected return of GMG is $9.20 \%$, and AZJ is $12.95 \%$. This expected return this paper calculated by the DDM formula:

$$
P=\frac{D_{0}(1+g)}{r-g}
$$

Based on the Morningstar (2017), the dividends paid by the June of 2015 for the GMG is $0.22 \$$, and $0.24 \$$ for the AZJ. The expected return of DDM is better than the return calculated by the CAPM in table 4 , the return calculated by the CAPM is the cost of equity. The distinction refers to the fact that CAPM considers more factors than DDM. The DDM method only calculate the expected return through focusing on the dividends, but the
CAPM will consider more factors such expected return, risk-free rate, and beta of the firms.

\section{VALUATION METHOD}

Firstly, Free Cash Flow will be used to calculate Equity Method (FCFE), which is a measurement of amount of cash that can be paid as dividend to equity shareholders after all expenses, reinvestment and debt repayment have been met.

\section{$\mathrm{FCFE}_{2012}=\mathrm{FCFF}$-interest payments* $(1-\mathrm{T})+$ net borrowing}

The firm value can be given:

$$
\text { value of firm }=\frac{\mathrm{FCFE} *(1+\mathrm{g})}{\mathrm{k}-\mathrm{g}}
$$

The second method is FCFF, the formula is given below:

$\mathrm{FCFF}_{2012}=\mathrm{EBIT}^{*}(1-\mathrm{T})+$ depreciation \& amortization-CAPEX- $\triangle \mathrm{NWC}$

The process of valuation of firm by FCFF is quite similar to that of FCFE, except that the required rate has been changed from cost of equity to WACC, meanwhile the arthur do not deduct the interest payment in FCFF method.

\section{TARGET FIRM VALUATION}

\subsection{Valuation of GMG}

The author uses FCFF to calculate the valuation of GMG. With high volatility and hard prediction of real estate industry, the author assumes seven years in the first prediction period before sustainable growth period. For the first year's prediction of income, the author assumed the growth rate is stable in near future and used the growth rate from $06 / 2014$ to $06 / 2015$. Then, after $06 / 2016$, the author uses the house price growth rate in 2015 as the next six years income growth rate. For other items, the author applies the same portion as the year of 2015. The sustainable growth rate after $06 / 2022$ is $3.6 \%$ and the discounted rate $\mathrm{WACC}$ is $6.2 \%$. These rates are calculated in Section 3. 
TABLE V. Fundamental VALUATION

\begin{tabular}{|c|c|c|c|c|c|}
\hline \multicolumn{6}{|c|}{ Fundamental valuation ( Discounted Cash Flow) of GMG } \\
\hline Pre 06/18 & Pre 06/19 & Pre 06/20 & Pre 06/21 & Pre 06/22 & $\begin{array}{l}\text { Sustainable } \\
\text { growth rate }\end{array}$ \\
\hline $233,359,043 \mathrm{~A}$ & $249,274,129$ & $266,274,625$ & $284,434,554$ & $303,832,991$ & $3.60 \%$ \\
\hline $4,475,715$ & $4,780,959$ & $5,107,020$ & $5,455,319$ & $5,827,3724$ & \\
\hline $1,330,389,418$ & $1,421,121,977$ & $1,518,042,495$ & $1,621,572,994$ & $1,732,164,272$ & $\leftarrow$ \\
\hline $1,568,224,176$ & $1,675,177,065$ & $1,789,424,141$ & $1,911,462,867$ & $2,041,824,635$ & 4 \\
\hline $404,502,040$ & $432,089,080$ & $461,557,555$ & $493,035,780$ & $526,660,820$ & $\leftarrow$ \\
\hline $8,045,926$ & $8,594,658$ & $9,180,814$ & $9,806,946$ & $10,475,779$ & + \\
\hline $1,069,498,655$ & $1,142,438,463$ & $1,220,352,766$ & $1,303,580,825$ & $1,392,485,037$ & \& \\
\hline $91,942,9944$ & $98,213,506$ & $104,911,667 \mathrm{~A}$ & $112,066,643 \mathrm{~A}$ & $119,709,588 \mathrm{~A}$ & $\leftarrow$ \\
\hline $8,045,926$ & $8,594,658$ & $9,180,814$ & $9,806,946$ & $10,475,779$ & $\leftarrow$ \\
\hline $4,632,503 \mathrm{~A}$ & $4,948,440 \mathrm{~A}$ & $5,285,923 \mathrm{~A}$ & $5,646,423\}$ & $6,031,509$ & 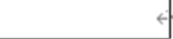 \\
\hline $439,532,938$ & $469,509,084$ & $501,529,604$ & $535,733,922$ & $572,270,976 \mathrm{~A}$ & $\leftarrow$ \\
\hline $541,436,147$ & $578,362,092$ & $617,806,386$ & $659,940,782$ & $704,948,743$ & $\leftarrow$ \\
\hline $465,839,117$ & $468,558,706$ & $471,294,171$ & $474,045,606$ & $476,813,103$ & $12,850,653,999$ \\
\hline
\end{tabular}

\begin{tabular}{|c|c|c|c|c|}
\hline \multicolumn{5}{|c|}{ Fundamental valuation ( Discounted Cash Flow) of GMG } \\
\hline Item & $06 / 14$ & $06 / 15$ & Pre $06 / 16$ & Pre $06 / 17$ \\
\hline Rental Income & $207,700,000$ & $206,100,000$ & $204,512,325$ & $218,460,066$ \\
\hline Investment Income & $9,800,000$ & $6,200,000$ & $3,922,449$ & $4,189,960$ \\
\hline Other Income & $989,500,000$ & $1,074,100,000$ & $1,165,933,108$ & $1,245,449,746$ \\
\hline Total Income & $1,207,000,000$ & $1,286,400,000$ & $1,374,367,882$ & $1,468,099,772$ \\
\hline cost & $457,000,000$ & $402,500,000$ & $354,499,453$ & $378,676,316$ \\
\hline Depreciation+Amertization & $6,200,000$ & $6,600,000$ & $7,051,328$ & $7,532,228$ \\
\hline EBIT & $743,800,000$ & $877,300,000$ & $937,292,400$ & $1,001,215,741$ \\
\hline -TAX Expense & $45,490,000$ & $75,420,000$ & $80,577,445$ & $86,072,827$ \\
\hline +Repreciation+Amortization & $6,200,000$ & $6,600,000$ & $7,051,328$ & $7,532,228$ \\
\hline - Capex & $2,800,000$ & $3,800,000$ & $4,059,855$ & $4,336,738$ \\
\hline - changes of NWC & $-431,300,000$ & $513,600,000$ & $385,200,000$ & $411,470,640$ \\
\hline FCFF & $1,133,010,000$ & $291,080,000$ & $474,506,427$ & $506,867,765$ \\
\hline $\begin{array}{l}\text { Present value of CF with WACC } \\
(6.2 \%)\end{array}$ & & & $460,447,204$ & $463,135,314$ \\
\hline Valuation of the firm & $16,130,787,220$ & 4 & 4 & \\
\hline
\end{tabular}

With DCF model, the enterprise value is AUD $16,130,787,220$. The intrinsic value per share is 7.53 .

TABLE VI. VALUATION

\begin{tabular}{|c|r|}
\hline $\begin{array}{c}\text { Valuation of the } \\
\text { firm }\end{array}$ & $16,130,787,220$ \\
\hline Long-term debt & $2,808,700,000$ \\
\hline Equity & $13,322,087,220$ \\
\hline $\begin{array}{c}\text { Out Standing } \\
\text { shares }\end{array}$ & $1,770,100,000.00$ \\
\hline Share value & 7.53 \\
\hline
\end{tabular}

\subsection{Valuation of AZJ}

As well as GMG, the author also uses FCFF to calculate the stock intrinsic price. The author assumes that 7 years would be an appropriate time span for sustainable growth period. For the first year's prediction of income, the author assumes the growth rate is stable in near future and uses the growth rate from $06 / 2014$ to $06 / 2015$. Then, after 06/2016, the author uses the Australian CPI in 2015 as the next 6 years income growth rate. 
TABLE VII.. FundAMENTAL VALUATION OF AZJ

\begin{tabular}{|c|c|c|c|c|}
\hline \multicolumn{5}{|c|}{ Fundamental Valuation (Discounted Cash Flow) of AZJ } \\
\hline Item & $06 / 14$ & $06 / 15$ & Pre 06/16 & Pre 06/17 \\
\hline Operating Revenue & $3,811,900,000$ & $3,732,000,000$ & $3,653,774,758$ & $3,708,581,379$ \\
\hline Other Revenue & $10,400,000$ & $48,000,000$ & $221,538,462$ & $224,861,538$ \\
\hline $\begin{array}{l}\text { Total Revenue Excluding } \\
\text { Interest }\end{array}$ & $3,822,300,000$ & $3,780,000,000$ & $3,875,313,220$ & $3,933,442,918$ \\
\hline Operating Expenses & $2,471,700,000$ & $2,271,000,000$ & $2,086,596,674$ & $2,363,187,531$ \\
\hline Depreciation & $321,900,000$ & $330,000,000$ & $338,303,821$ & $343,378,378$ \\
\hline Amertisation & $177,300,000$ & $189,000,000$ & $201,472,081$ & $204,494,162$ \\
\hline $\begin{array}{l}\text { Depreciation and } \\
\text { Amertisation }\end{array}$ & $499,200,000$ & $519,000,000$ & $539,775,902$ & $547,872,541$ \\
\hline EBIT & $851,400,000$ & $990,000,000$ & $1,248,940,643$ & $1,267,674,753$ \\
\hline -TAX EXPENSE & $134,230,000$ & $271,500,000$ & $342,512,510$ & $347,650,197$ \\
\hline $\begin{array}{l}\text { +Depreciation and } \\
\text { Amertisation }\end{array}$ & $499,200,000$ & $519,000,000$ & $539,775,902$ & $547,872,541$ \\
\hline -CAPEX & $870,400,000$ & $1,083,000,000$ & $1,099,245,000$ & $1,115,733,675$ \\
\hline $\begin{array}{l}\text {-change of Net Working } \\
\text { Capital }\end{array}$ & $132,400,000$ & $-248,400,000$ & $-58,000,000$ & $-58,870,000$ \\
\hline FCFF & $213,570,000$ & $402,900,000$ & $404,959,036$ & $411,033,421$ \\
\hline $\begin{array}{l}\text { Present value of CF with } \\
\text { WACC }(4.89 \%)\end{array}$ & $4.89 \%$ & 4 & $395,406,724$ & $382,627,348$ \\
\hline Valuation of the Firm & $23,616,316,635$ & 1 & 1 & + \\
\hline
\end{tabular}

As the CAPEX changes dramatically, the author used the CPI as the growth rate the first prediction year. For NWC, the author get an average value of 2014 and 2015. For other items, the author used the same portion as the year of 2015. The sustainable growth rate after $06 / 2022$ is $1.72 \%$ and the discounted rate WACC is $4.89 \%$. These rates are calculated in section 3 .

TABle VIII. VAluation

\begin{tabular}{|l|r|}
\hline Valuation of the firm & $10,152,034,799$ \\
\hline Long-term debt & $3,051,741,112$ \\
\hline Equity & $7,100,293,688$ \\
\hline Out Standing shares & $2,099,200,000$ \\
\hline Share value & 3.38 \\
\hline
\end{tabular}

With DCF model, this paper calculates the enterprise value is AUD 23,616,316,635. The intrinsic value per share is 3.38 .

\section{MERGERS AND ACQUISITIONS}

\subsection{The attractiveness of these two companies}

From the valuation calculated in section 6 , the GMG is with an intrinsic value premium $-3.95 \%-24.05 \%$ and the $\mathrm{AZJ}$ is with an intrinsic value premium $-6.37 \%-54.02 \%$.

TABLE IX. ESTIMATION

\begin{tabular}{|l|l|l|l|}
\hline Stock & Estimated Stock price & Market Price (January 27, 2016) & Premium \\
\hline GMG & $5.83-7.53$ & 6.07 & $-3.95 \%-24.05 \%$ \\
AZJ & $3.38-5.56$ & 3.61 & $-6.37 \%-54.02 \%$ \\
\hline
\end{tabular}

TABle X. Ratio AnAlysis

\begin{tabular}{|l|l|l|l|l|l|}
\hline Stock & Current ratio & Quick ratio & P/B ratio & P/E ratio & D/E ratio \\
\hline GMG & 2.21 & 1.67 & 1.49 & 17.27 & 1.53 \\
\hline AZJ & 1.03 & 0.82 & 1.67 & 17.54 & 1.74 \\
\hline
\end{tabular}

From table 10, the current ratio and quick ratio of GMG and AZJ are high, which means they have more liquidity and low financial risk. The low $\mathrm{D} / \mathrm{E}$ ratio is also consistent with the condition of low financial risk. Low $\mathrm{P} / \mathrm{B}$ ratio means Jaffa doesn't have to pay high intangible assets' premium to target shareholders. Low $\mathrm{P} / \mathrm{E}$ ratio, 
which means GMG and AZJ are mature business and have stable profit earning.

\subsection{Cash versus Share offer}

In cash offer, the acquiring shareholders take on the entire risk. In stock offer transaction, the risk is shared with selling shareholders.
The author assume there is no premium in merger. Then author calculate the result as table 11 shows.

\begin{tabular}{|c|c|c|c|c|c|c|}
\hline \multicolumn{7}{|c|}{ TABle XI. CASH OfFer VS StOCK OfFER } \\
\hline 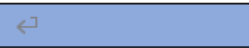 & \multicolumn{3}{|c|}{ Cash Offer } & \multicolumn{3}{|c|}{ Stock Offer } \\
\hline Merger & $\begin{array}{l}\text { Earnings } \\
\text { per } \\
\text { share(\$) }\end{array}$ & $\begin{array}{l}\text { Stock } \\
\text { price } \\
(\$) \\
\end{array}$ & $\begin{array}{l}\text { Outstanding } \\
\text { shares }\end{array}$ & $\begin{array}{l}\text { Earnings } \\
\text { per } \\
\text { share(\$) }\end{array}$ & $\begin{array}{l}\text { Stock } \\
\text { price } \\
(\$) \\
\end{array}$ & $\begin{array}{l}\text { Outstanding } \\
\text { shares }\end{array}$ \\
\hline Jaffa\&GMG & 34 & 30.00 & $1,000,000,000$ & 2.68 & 22.09 & $1,358,150,233$ \\
\hline Jaffa\&AZ & 34 & 30.00 & $1,000,000,000$ & 2.88 & 23.95 & $1,252,603,733$ \\
\hline Jaffa\&GMG\&AZI & 34 & 30.00 & $1,000,000,000$ & 2.64 & 18.62 & $1,610,753,967$ \\
\hline
\end{tabular}

With cash offer, Jaffa has to obtain extra cash from other ways, such as issue bonds or bank lending. It will increase its financial risk. Jaffa only has four billion dollars cash. The cash offer total value is as below the market value of each company.

Table XII. Market Value of Two Companies

\begin{tabular}{|l|c|c|c|}
\hline Company & $\begin{array}{c}\text { Stock } \\
\text { price } \\
(\$)\end{array}$ & $\begin{array}{c}\text { Outstanding } \\
\text { shares }\end{array}$ & $\begin{array}{c}\text { Market Value } \\
(\$)\end{array}$ \\
\hline GMG & 6.07 & $1,770,100,000$ & $10,744,507,000$ \\
\hline AZ & 3.61 & $2,099,200,000$ & $7,578,112,000$ \\
\hline
\end{tabular}

\section{CONCLUSION}

\subsection{Acquired cash reserves}

The author recommend Jaffa holding cash until the finish of takeover. The reason for that is because the takeover would be accomplished by raising debt rather than cash or equity, and chairman of Jaffa is keen to deliver values to shareholders, hence, the author decide to use this fund to deliver the dividends to shareholders after acquisition. The reason for raising the debt is that the Jaffa has excellent debt capacity, and even after the acquisition, as figure 5 shown, it still has strong capacity to raise funds by debt.

\subsection{Potential synergy gains}

GMG's main business is real estate. It can provide Jaffa with commercial estate to reduce the cost of renting shop front. The AZJ's main business is transportation, which can reduce Jaffa's cost of commodity transportation. The merger can also help shareholders diversify industry risk.

\begin{tabular}{|l|rr|rr|}
\hline Jaffa & \multicolumn{2}{|c|}{ After acquistion } & \multicolumn{2}{l|}{ Before acquisition } \\
\hline Value of debt & $\$$ & $79,573,000,000.00$ & $\$$ & $60,000,000,000.00$ \\
\hline Value of equity & $\$$ & $272,000,000,000.00$ & $\$$ & $272,000,000,000.00$ \\
\hline Cost of debt & $7.00 \%$ & $7.00 \%$ \\
\hline Cost of equity & $7.64 \%$ & $7.64 \%$ \\
\hline Tax & $30.00 \%$ & $30.00 \%$ \\
\hline D/E & $29.25 \%$ & $25.00 \%$ \\
\hline Enterpirse value & $\$$ & $351,573,000,000.00$ & $\$$ & $300,000,000,000.00$ \\
\hline WACC & $7.02 \%$ & $7.91 \%$ \\
\hline
\end{tabular}

Figure V. The capital structure of Jaffa 


\subsection{Whether to Approve this Takeover}

This paper recommends Jaffa to acquire AZJ and GMG at price $\$ 5.56$ and $\$ 7.53$, respectively. There are several reasons for acquiring the AZJ and GMG. According to the section 1, the growth rate of commercial property management industry is quite high; even the growth rate of rail freight transport industry is only $0.6 \%$, it expected to reach to $2.6 \%$. Another reason for acquiring these two firms is that after the acquiring would increase $\mathrm{D} / \mathrm{E}$ ratio, which means the capital structure of Jaffa will be improved. As the Figure 3 shown, the Jaffa's WACC of post-acquisition decreased from $7.91 \%$ to $7.02 \%$, and its enterprise value increased a lot. In section 5, two methods that the author used to evaluate the value of two target firms have been clearly presented, therefore the author can make a valid valuation of target firms. Furthermore, according to section 6, using the share price of these two companies on the 27 th of January 2016 to multiply their maximum premium, the reason for it is that the author have to know what the maximized price Jaffa need to pay, which would be helpful for Jaffa to plan how much funds they should raise operating synergies, which are from short front rental cost reduction and transportation cost reduction. In terms of the recommended offer price, the takeover is calculated through.

\section{REFERENCES}

1. Aurizon Holding Limited. Aurizon Holding Limited: 2015 annual report. Retrieved fromhttps://www.aurizon.com.au/ /media/aurizon/fil es/investors/documents\%20and\%20webcasts/2015/f ull\%20year\%20results/annual\%20report\%202015.pd $\mathrm{f}$

2. Australia government. (2016). Composition of trade Australia 2016. Retrieved from http://dfat.gov.au/about-us/publications/Documents/c ot-cy-2016.pdf

3. Damodaran. A. (2011). Applied Corporate Finance. New York, U.S: New York University

4. Fenebris. (2017). Implied Market-risk-premia (IMRP): Australia. Retrieved from: http://www.market-risk-premia.com/au.html

5. Fullerton, A. (May 05, 2014). M\&A: One question you don't want to be asking yourself at the closing table. Retrieved from http://merger.com/ma-question-dont/

6. Goodman Group. (2015). Goodman Group: 2015 annual report. Retrieved from http://www.goodman.com/-/media/Files/Sites/Global /Investor\%20Centre/GMG\%20Goodman\%20Group/ reports $\% 20$ and $\% 20$ newsletters/Annual\%20Reports/2 0150928\%202015\%20Annual\%20Report.pdf?la=en

7. McGrego, W. (2017, August). Rail Freight Transport in Australia (IBIS World Industry Report 14710). Retrieved

from http://clients1.ibisworld.com.au.ezproxy.lib.monash. edu.au/reports/au/industry/default.aspx?indid=1888
8. McGrego, W. (2017, June). Commercial Property Management in Australia (IBIS World Industry Report OD5433. Retrieved from http://clients1.ibisworld.com.au.ezproxy.lib.monash. edu.au/reports/au/industry/ataglance.aspx?entid $=543$ 3

9. Morningstar. (2017). Aurizon Holding Limited per share statistics. Retrieved from http://www.morningstar.com.au/Stocks/CompanyHis toricals/AZJ

10. Morningstar. (2017). Goodman Group per share statistics. Retrieved from http://www.morningstar.com.au/Stocks/CompanyHis toricals/GMG

11. Morningstar. (2016, January 28). Aurizon Holdings Limited. Retrieved from http://datanalysis.morningstar.com.au.ezproxy.lib.m onash.edu.au/af/company/fullcompanyreport?ASXC ode $=$ AZJ $\&$ licensee $=$ datpremium $\& x s 1 \% \mathrm{C} 2 \% \mathrm{ADprint}$ friendly $=\mathrm{ye} \% \mathrm{E} 2 \% 80 \% \mathrm{~A} 6$

12. Morningstar. (2016, January 28). Goodman Group. Retrieved from http://datanalysis.morningstar.com.au.ezproxy.lib.m onash.edu.au/af/company/fullcompanyreport?ASXC ode $=$ GMG $\&$ licensee $=$ datpremium $\&$ xs1 $\%$ C2 $\%$ ADpri ntfriendly $=\mathrm{y} \% \mathrm{E} 2 \% 80 \% \mathrm{~A} 6$

13. OECD. (2015). Trade in goods and services. Retrieved from https://data.oecd.org/trade/trade-in-goods-and-servic es.htm

14. Strategic Exits. (n.d.). M\&A Advisor Fees for Selling a Business. Retrieved from http://www.exits.com/blog/ma-advisor-fees-selling-b usiness/

15. Thirlwell, M. (2017). Australia's export performance in 2015-16. Retrieved from https://www.austrade.gov.au/news/economic-analysi s/australias-export-performance-in-2015-16

16. Trading Economics. (2017). Australia | Economic Indicators. Retrieved from https://tradingeconomics.com/australia/indicators

17. Yahoo finance. (2017). Goodman Group. Retrieved from

https://au.finance.yahoo.com/quote/GMG.AX/histor y?period $1=1296046800 \&$ period $2=1435586400 \&$ inte rval $=1 \mathrm{~d} \&$ filter $=$ history $\&$ frequency $=1 \mathrm{~d}$ 